Andrzej MAMCARZ

\title{
DIFFERENTIATION OF BODY SIZE IN TWO COREGONID SPECIES UNDER CONDITIONS OF LONG-TERM CULTURE IN ILLUMINATED CAGES
}

\author{
RÓŻNICOWANIE SIĘ ROZMIARÓW CIALA DWU GATUNKÓW \\ RYB GLĄBIELOWATYCH (COREGONIDAE) W WARUNKACH \\ DLUGOTRWAEEGO CHOWU W' SADZACH OSWWIETLONYCH
}

\author{
Chair of Fisheries, \\ Academy of Agriculture and Technology, Olsztyn
}

\begin{abstract}
Changes in population structure of two coregonid species (Coregonus lavaretus $\mathrm{L}$. and C. peled Gmel.) kept in illuminated cages from hatching until maturity are a result of concrted action of a number of ecological factors, food resources playing the key role. The analysis of long - term trends in body size variability and in changes within each stock allows to reconstruct the conditions of growth in cages and to indicate certain critical periods in fish life.
\end{abstract}

\section{INTRODUCTION}

The phenotypic variability, i.e. the level of differentiation in a natural or experimental population, observed under certain conditions and in a defined period of time results from a number of processes which are an effect of a combination of genetic and environmental factors (Sluckij, 1978). Differences between individuals are affected by processes governing the mortality level in a population. Variability is more and more frequently considered a control mechanism of population dynamics (Łomnicki, 1980). A number of within-population phenomena such as hierarchy and competition for food and space influence the variability to a significant degree (Poljakov, 1960; Yamagishu, 1969; Mashiko, 1976; Nakamura and Kasahara, 1977a, b, c, d; Wohlfarth, 1977; Ruban, 1977; Gerకanovič, 1983). So far, body size differentation in plankton-f́eeảing coregonids in intensive cultures has not been dealt with. First attempts to study coregonid variability in cage culture were made in the early 80 's only (Tišenko, 1981). 
In 1977-1980, the first Polish attempt to keep Goregonus spawners in fully controlled illuminated cage cultures was made (Mamcarz and Szczerbowski, 1984). Apart from a number of results showing the culture output, the 4-yr period of culture yielded also preliminary data on size differentiation in Coregonus lavaretus L. and C. peled Gmel. Their presentation is the author's aim in this paper.

\section{MATERIALS AND METHODS}

Both species were kept under controlled conditions in cages placed in the Leginskie Lake situated upstream the river Sajna (the Łyna-Pregoła drainage). Culture methods, fish growth and survival as well as environmental conditions and techniques used to monitor them were discussed earlier (Mamcarz and Szczerbowski, 1984; Szczerbowski and Mamcarz, 1984).

The experiment involved $8 \mathrm{~m}^{3}$ capacity cages. At the first stage, 1.0 and $1.8 \mathrm{~mm}$ mesh size polyethylene netting was used in cage construction. After 5 months, the fish were transferred to $5.5 \mathrm{~mm}$ mesh size net cages where they were kept until the experiment was terminated. Photocell-controlled illumination $(24 \mathrm{~V} / 60 \mathrm{~W})$ inside the cage was used to bait natural food. The fish were wintered in the same cages, under ice, at $24 \mathrm{~h}$ illumination. To analyse size differentiation of fish during a long-term cage culture, data on 3 stocks ( 2 cages with $C$. peled and one with $C$. lavaretus) with no marked changes introduced to the stocking density were used. The initial $C$. lavaretus stocking density was 5,832 larvae per $\mathrm{m}^{3}$. The density in the cage was not interfered with throughout the entire experiment. One cage was stocked with $C$. peled at a density of $12,500 \mathrm{ind} . / \mathrm{m}^{3}$. Two months later the stock was divided into 3 cages with densities of 1,$969 ; 1,313$; and 657 ind. $/ \mathrm{m}^{3}$. A detailed description of stocking density-dependent size variability of C. peled during the first year was given in a separate paper (Mamcarz, 1984). The present paper is restricted to a brief characteristics of changes in extreme densities over the same period of time. As of the second year until the end of the experiment, stock densities in the two cages with $C$. peled maintained a ratio of $1: 4$ (Fig. 1).

The larvae and 0+ fry were sampled every week, while samples of older fish were collected once or twice a month. The fish were weighed to $1 \mathrm{mg}$ (larvae) and $1 \mathrm{~g}$ (older fish). Total fish length was measured to $0.1 \mathrm{~mm}$. A total of 814 and 3,204 individuals of $C$. lavaretus and $C$. peled were examined, respectively.

Variability in fish size was described by means of the coefficient of variation (CV) calculated from separated series generated with the Sterdgess formula (Balicki and Bielecki, 1980). Changes in stock structure during the growth period in cages were assessed with the coefficient of skewness (Nakamura and Kasahara, 1977a) as follows:

$$
\mathrm{SK}=\frac{1}{\sigma^{3}} \cdot \frac{1}{\mathrm{~N}} \Sigma \mathrm{f}_{\mathrm{i}}\left(\mathrm{x}_{\mathrm{i}}-\overline{\mathrm{x}}\right)^{3}
$$

where $\frac{1}{\mathrm{~N}} \Sigma \mathrm{f}_{\mathrm{i}}\left(\mathrm{x}_{\mathrm{i}}-\overline{\mathrm{x}}\right)^{3}=\mu_{3}$ is the third order central moment. Since Sk has no defined 


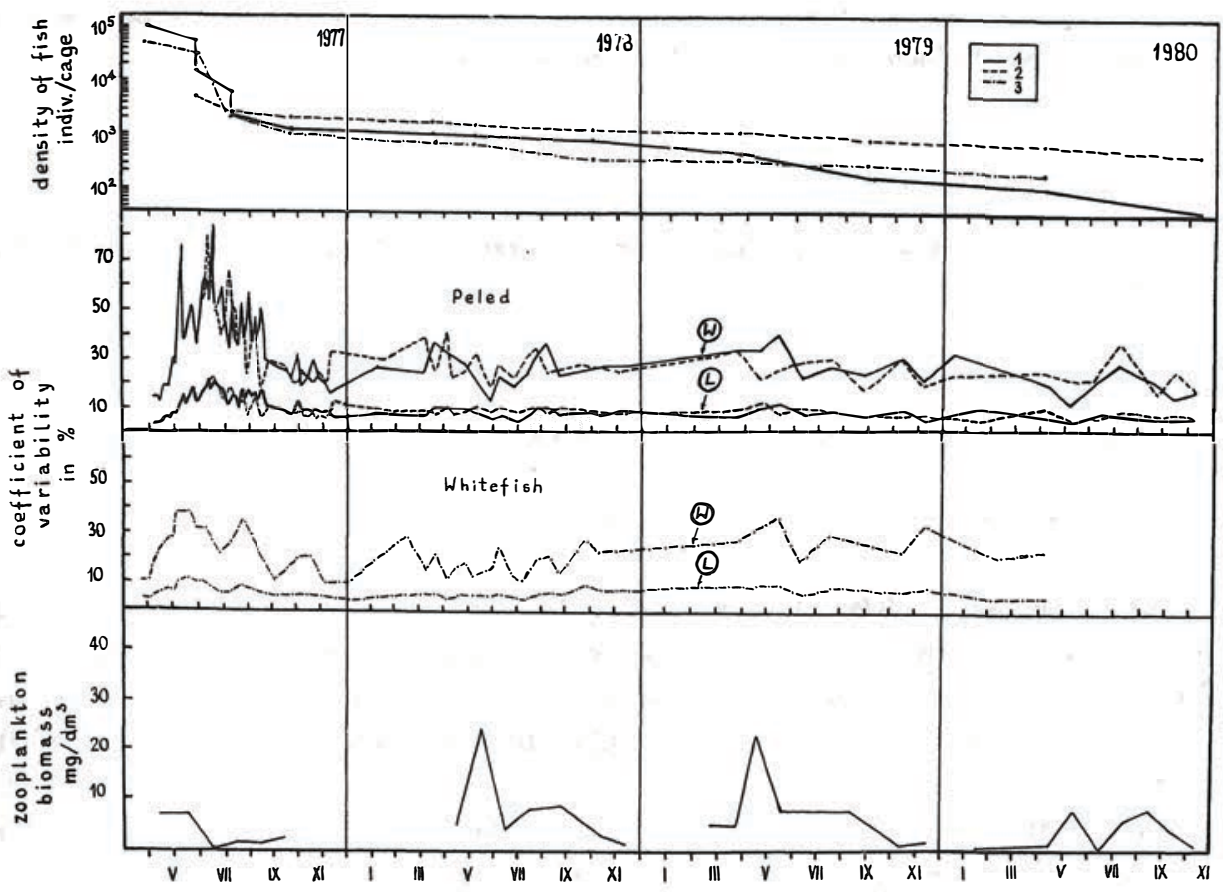

Fig. 1. Variability of length (L) and weight (W) of Coregonus lavaretus and C. peled kept in illuminated cages against the background of changes in stocking density and zooplanktion biomass in Lake Legińskie within 1977-1980

1 and 2: cages with $C$. peled with initial densities of 1,969 and 657 ind. $/ \mathrm{m}^{3}$ in July 1977 ; 3: cage with $C$. lavaretus

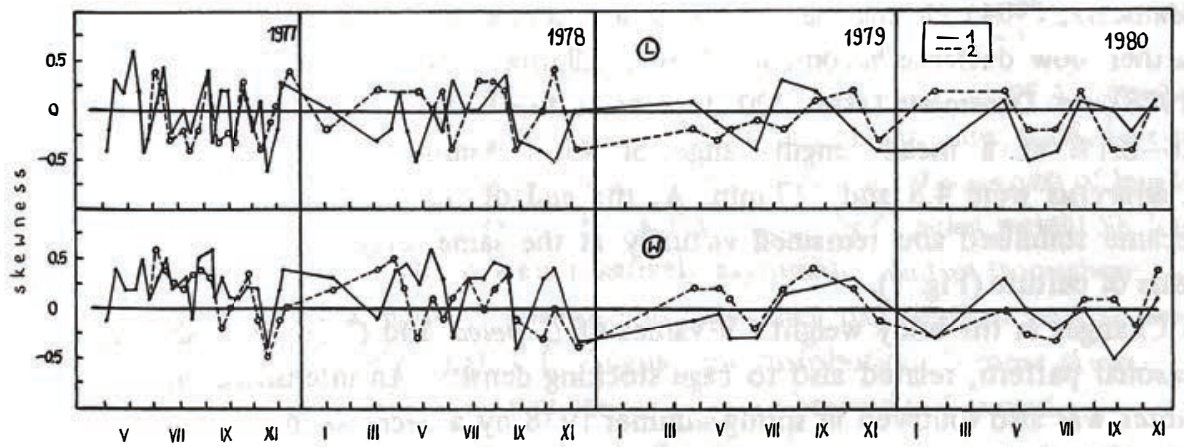

Fig. 2. Changes in coefficient of skewness of $C$. peled length (L) and weight (W) distributions during culture in illuminated cages in Lake Legińskie within 1977-1980; for explanations see Fig. 1. 
numerical range, the following modification of the formula proposed by Krzysztofiak (1966) was used to facilitate interpretation of the data:

$$
\mathrm{SK}=\frac{\mu_{3}}{\sigma^{3}+\left|\mu_{3}\right|}
$$

Owing to the module $\mathrm{u}_{3}$ being added in the denominator, all SK values are in the range of $-1<\mathrm{SK}<1$.

\section{RESULTS}

Size variability of $C$. lavaretus and $C$. peled

During the initial stage of growth in cages (until the yolk sac was resorbed), size differentiation of the larvae was similar between the two species. The CV values for C. peled and $C$. lavaretus body length were $3.5 \%$ and $4.5 \%$, respectively. The respective mean lengths were 9.4 and $12.5 \mathrm{~mm}$. Variability in body weight of $C$. peled was $13.5 \%$ (at a mean weight of $4.1 \mathrm{mg}$ ), while the corresponding $\mathrm{CV}$ value for $C$. lavaretus was $11.1 \%$ (mean weight of $9.8 \mathrm{mg}$ ). Once the larvae switched to the external food, their size underwent a considerable differentiation (Fig. 1). Toward the end of the larval period, size differentiation was 3-5 times greater than recorded initially. A sizeable increase in fish weight variability was observed as well. As soon as on the 40th day of culture, the weight CV exceeded $70 \%$ in C. peled and reached about $40 \%$ in C. lavaretus. The maximum variation in fish size occurred during the summer stagnation (July-August), when the zooplankton biomass decreased in the lake and a resultant growth retardation of the two species ensued. At that time, the $C$. peled growth variability in the highest-density cage (cage 1 ) reached $83.1 \%$ at a mean individual weight of $238 \mathrm{mg}$. The variability in $C$. lavaretus was lower by half. Regardless of stocking density, all the cages exhibited characteristic peaks of variability followed by a marked reduction in variation (Mamcarz, 1984). During the autumn growth acceleration, size variability was subject to a further slow decrease accompanied by oscillation in CV values as described by Sluckij (1978). In December (after 220 days of culture), the $C$. peled size CV ranged within $4.6-8.1 \%$ at a mean length range of $95-110 \mathrm{~mm}$. The corresponding values for C. lavaretus were 4.8 and $117 \mathrm{~mm}$. At the end of the first the body length variability became stabilised and remained virtually at the same level throughout the subsequent years of culture (Fig. 1).

Changes in the body weight $\mathrm{CV}$ values of $C$. peled. and $C$. lavaretus showed a certain seasonal pattern, related also to cage stocking density. An intensified differentiation in winter was also followed in spring-summer 1978 by a decrease in CV down to $12-17 \%$. The largest decrease was observed in the C.peledcontaining cage 1 with the lowest density (about 125 ind. $/ \mathrm{m}^{3}$ ) (Fig. 1). The 1978 summer stagnation with its decrease in food biomass again yielded an increased variability in body weight of the two species. In 
late August, the $C$. peled CV ranged within $24-34 \%$ (at a mean individual weight of 20-40 g). The pattern was repeated in 1979 (Fig. 1). Irrespective of the fish growth retardation, outbreak of an unknown disease lasting until the end of the summer stagnation, was observed (Waluga, 1980). In spite of the low density, the disease resulted in a $63 \%$ loss of the stock. As late as at the end of September $16.4 \%$ of the surviving fish showed open wounds and lesic:s, healing gradually (Mamcarz, 1982). The epizootics, showing symptoms of a prolonged bacterial invasion, caused the fish growth differentiation to increase out of proportion to the stock density in the cage (Fig. 1).

After 3 years of keeping $C$. peled in strongly differentiated a marked deviation in growth of the two populations was observed (Mamcarz, 1982). In spring 1980, the $C$. peled individuals in cage 1 attained $134 \mathrm{~g}$ mean individual weight, as little as $52,4 \mathrm{~g}$ being reached by the fish in cage 2 . At the same time, the corresponding value for C. lavaretus was $111 \mathrm{~g}$. Similarly to previous years, fish weight variability during the spring growth tended to decrease. In June, the $C$. peled $\mathrm{CV}$ values ranged, depending on density, within $12.1-22.3 \%$, while the $C$. lavaretus body weight CV was $24.4 \%$. The 1980 summer stagnation was accompanied by a renewed increase in weight variability, the variability being gradually reduced in autumn (Fig. 1).

\section{Changes in $C$. lavaretus and $C$. peled stock structure during cage growth}

Panmictic populations existing under natural conditions show most of their quantitative characters to be distributed in a manner approaching the normal distribution. As a result of a non-uniform growth of various individuals in culture, resulting from a number of processes taking place within a stock, the "normality" may become strongly altered, which leads to the distributions being skewed to the left or to the right.

During the cage culture of $C$. lavaretus and $C$. peled, the structure of their stocks changed several times as reflected in oscillations of the skewness coefficient SK. The oscillations showed similar trends with respect to body length and weight. Moreover, in spite of considerable differences between the SK values of the two $C$. peled stocks, the trends in this case were similar as well (Fig. 2). On the other hand, the course of changes differed somewhat between the $C$. lavaretus and $C$. peled stocks (Figs. 2 and 3 ).

During the first year of culture, the $C$. peled length distribution showed a clear-cut positive asymmetry (SK $>0.5)$ as early as after the first month. As of June, until the end of the year, extensive SK oscillations and changes in the direction of skewness of length distributions in both stocks were observed. The oscillations in the $C$. peled weight SK had a smaller amplitude; the distributions were positively asymmetric almost throughout the year. At the initial stage of keeping $C$. lavaretus in cages their distributions were skewed to the left (SK $<-0.5$ for body length). In August, the distributions became skewed to the right, while in autumn the skewness was similar to that observed in C. peled.

In the second year of the cage culture, the body dimensions distribution skewness in the two species continued to oscillate between negative and positive values within a broad range of $-0.5<\mathrm{SK}<0.5$, which was particularly evident during the summer stagnation. 


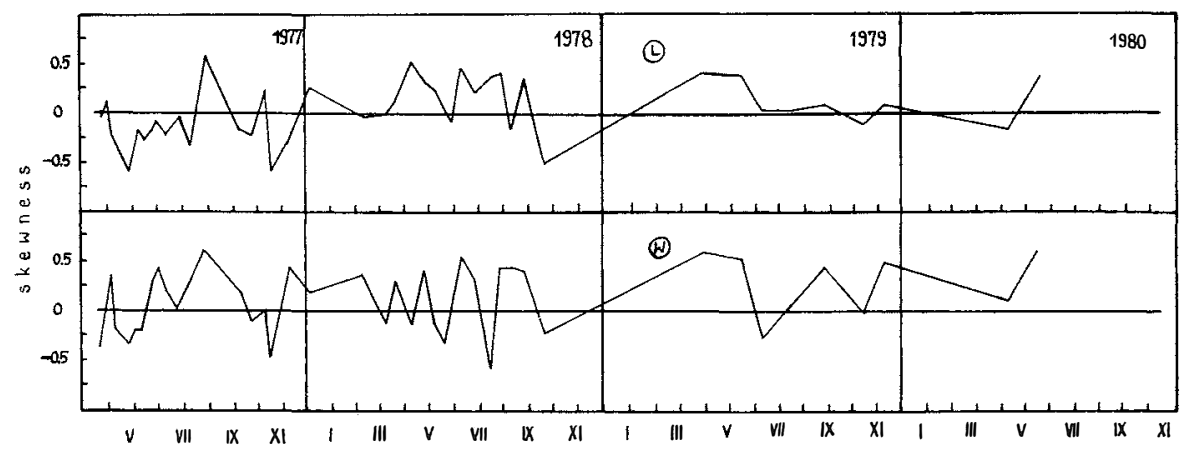

Fig. 3. Chanes in coefficient of skewness of $C$. lavaretus length (L) and weight (W) distributions during culture in illuminated cages in Lake Legińskie within 1977-1980

It was only the $C$. lavaretus length distribution that showed a positive asymmetry throughout most of the year (Fig. 3).

In the third and fourth year of cage culture, the length and weight distributions of the two $C$. peled stocks showed certain differences (Fig. 2). In 1979, the length distribution of the cage 1 individuals subject to the disease had a lower skewness than that in cage 2 , a reverse situation being observed in weight distributions. The situation seems to reflect changes in fish condition, the changes being brought about by the disease which caused growth retardation in some individuals. The different nature of asymmetry in both C. peled stocks was observed in 1980 as well: distributions in cage 1 were definitely skewed to the left, which probably resulted irom differing growth and maturation rates in the stock affected by the disease. An increased negative asymmetry in distributions in the two stocks was particularly marked in autumn 1980 when the gonadosomatic coefficients were strongly variable within the two stocks.

\section{DISCUSSION}

A number of reasons have been invoked to explain variability between individuals in a stock during the period of growth. The stock dynamics theory formulated by Nikolski (Lapin, 1981) is one of the most frequently quoted explanations. It assigns an adaptive value to the variability. According to Nikolski, an increase in variability, resulting from deteriorating conditions of the population's life, broadens the fish food spectrum and weakens the intraspecific competition. Studies of Suchanov (1981) demonstrate the presence of a certain feedback between the habitat and variability among individuals and allow to describe variability as a population's response to environmental stimuli. According to Łomnicki (1980), variability among individuals results from a non-uniform food resources partitioning in the population and is the prerequisite of its stability. The non-uniform growth of various length classes as measured with the coefficient of 
skewness reflects structural changes in a stock (Poljakov, 1970; Konikoff and Lewis, 1974; Mashiko, 1976; Kochanova, 1979). These, as a rule, are associated with changes in feeding conditions, which is expressed as asymmetry of size distributions in a stock consisting of individuals of equal age. At an extreme diet differentiation (e.g. in predatory fish), the distributions may become bimodal (Chodorowski, 1975). Additionally, ethologic phenomena like hierarchy, territorialism and others are of a paramount importance in shaping the stock structure (Yamagishi, 1969; Mashiko, 1976; Thorpe, 1977).

As demonstrated by observations made on coregonids confined to a restricted space, changes in stock structure result from a concerted action of a number of ecological variables. Due to the specific nature of fish culture in illuminated cages, food resources seemed to have played a key role. These effects were at their strongest during the period of larval growth (Mamcarz, 1984). Once the larvae switched to the food taken up from the water column, the competition between individuals led not only to differentiation of their size, but also retarded the development of some of them (Mamcarz, 1982). This was expressed by the negative asymmetry of the $C$. lavaretus larval size distributions and also by the "shoot carp" phenomenon, described by Wohlfarth (1977), in C. lavaretus. At the critical point, elimination of some of the weakest individuals brought the stock again to a certain equilibrium between the amount of food available and stock derisity. Against the background of food-density interactions, other processes played intermittently the key role, too. One may point to effects of diatom blooms on fish larvae (Mamcarz and Worniałło, 1986). A continous pressure of various parasites and epizootics (Waluga, 1980) was an extra stimulus reinforcing the key factor. The summer stagnation, a period when effects of limiting factors were cumulated, played a particular role in the cage culture. All those processes were associated with an increased mortality or decreased condition of some individuals, expressed through increased size differentiation and structural changes in stocks. Sexual maturation was the only period of increased size variability without increased mortality. However, the abnormal course of the maturation, determined by conditions of cage culture, cannot be excluded (Worniałło and Mamcarz, 1985; Mamcarz and Worniałło, 1985). The complexity of limiting factors and their mutual modifications make the evaluation of their respective roles in shaping the stock size structure difficult. However, analyses of long-term trends in fish size variability and ratios between various length classes can be instrumental in approximating conditions of fish growth in cages and in defining certain critical periods in fish life.

\section{REFERENCES}

Balicki A., Bielecki J., 1980: Metody statystyczne w rybołówstwie. [Statistical methods in fisheries]. - Studia i Mat., E, 41, MIR.

Chodorowski A., 1975: Formation de populations bimodales chez les alevins de poissons carnassiers.Verh. Internat. Vere in Limnol., 19: 2546-2555. 
Gerక̌̌anovǐ̌ A., 1983: Faktory opredeljajušçie izmenenija skorosti rosta i raspredelenie osobej po razmeram v gruppach molodi veslonosa Polyodon spathula Walbaum (Polyodontidae). - Vopr. ichtiol., 23, 4: 584-589. (in Russian)

-Kochanowa G.D., 1979: Osobennosti pitania molodi sazana polư̌enoj pri raznych temperaturnych režimach inkubacii ikry. - Ryb. Choz. Kiev, 28: 50-53. (in Russian)

Konikoff M., Lewis W.M., 1974: Variation in weight of cage reared channel catfish. - Progr. Fish-Cult., 36,3: 138-144.

Krzysztofiak M., 1966! O miarach symetrii i ekscesu. [On the measures of asymmetry and excess] Przegl. statyst., 4: 403.

Lapin J.S., 1981: Osnovnye metodologiלeskie koncepcii G.W. Nikolskogo $\mathrm{v}$ teorii dinamiki stada ryb. - Sovremennye problemy ichtiologii, Moskva, Nauka: 46-64. (in Russian)

Lomnicki A., 1980: Zróżnicowanie osobników a regulacja zagęszczenia populacji. Differentiation of individuals and population density regulation. - Wiad. ekol., 26, 4: 361-390.

Mamcarz A., 1982: Zmienność cech biometrycznych pelugi (Coregonus peled Gmelin, 1788) podczas jej chowu w sadzach jeziorowych. [Variability in biometric characters of Coregonus peled Gmelin, 1788 during cage rearing in lakes]. - Inst. Ichtiob. i Ryb., ART w Olsztynie, praca doktorska. [Dissertation]

Mamcarz A., Szczerbowski J.A., 1984: Rearing of coregonid fishes (Coregonidae) in illuminated lake cages. I. Growth and survival of Coregonus lavaretus L. and Coregonus peled Gmel. - Aquaculture, 40: $135-145$.

Mamcarz A., 1984: Rearing of coregonid fishes (Coregonidae) in illuminated lake cages. III. Phenotypic variability in body size of Coregonus peled Gmel. during the first year. Aquaculture, 40: 241-250.

Mamcarz A., Worniałło E., 1985: Rearing of coregonid fishes (Coregonidae) in illuminated lake cages. V. Gonad development in peled (Coregonus peled Gmel.) under conditions of cage culture. Aquaculture, 49: 41-54.

Mamcarz A., Worniał ło E., 1986: Effect of diatom blooms on the gills of whitefish (Coregonus lavare tus L.) reared in illuminated cages. - Aquaculture, 53: 1-5.

Mashiko K., 1976: Growth and survival of an eleotrid goby, Odontobutis obscurus (Temminck et Schlegel), with special reference to density and shelter effects. - Jap. J. Ecol., 26: 229-241.

Nakamura N., Kasahara S., 1977a: A study on the phenomenon of the Tobi-Koi or shoot carp. I. On the earliest stage at which the shoot carp appears. - Bamidgeh, 29, 2: 41-44.

Nakamura N., Kasahara S., 1977b: A study on the phenomenon of the Tobi-Koi or shoot carp. II. On the effect of particle size and quality of the food. - Bamidgeh, 29, 2: 44-47.

Nakamura N., Kasahara S., 1977c: A study on the phenomenon of the Tobi-Koi or shoot carp. III. On the result of culturing the modal group and the growth of carp fry reared individually. - Bamidgeh 29, 2: 48-52.

Nakamura N., Kasahara S., 1977d: A study on the phenomenon of the Tobi-Koi or shoot carp. IV. Effects of adding a small number of larger individuals to the experimental batches of carp fry and of culture density upon the occurrence of shoot carp. - Bamidgeh, 29, 2: 53-56.

Poljakov G.D., 1960: Prisposobitelnye izmienienija razmernovesovoj struktury odnovozrastnoj populjacii ryb v svjazi s uslovjami pitanija. - Vopr. ichtiol., 16: 1-33. (in Russian)

Poljakov G.D., 1970: Zakonomernost' izmen Civosti organizmov na primere s rybami. - Vopr. ichtiol., 10, 2: 194-202. (in Russian)

Ruban G.I., 1977: Vlijanie obespečennòsti pišcej na izmenčivost' dliny tela i velið̌iny nekotorych plastið̌eskich priznakov molodi belogo amura. - Nauð. dokl. vyšs. ふ̌koly, Biol. n., 2: 60-66. (in Russian)

Sluckij E.S., 1978: Fenotipið̌eskaja izmen ̌ivost' ryb (selekcionnyj aspekt). - Izv. GosNIORCh, 134: 3-132. (in Russian) 
Suchanov W.I., 1981: O svjazi meždu kormovymi uslovjami i izmenčivostju vesovogo rosta Životnych. - Vopr. ichtiol., 21, 2: 279-283. (in Russian)

Szczerbowski J.A., Mamcarz A., 1984: Rearing of coregonid fishes (Coregonidae) in illuminated lake cages. II. Environmental conditions during fish rearing. - Aquaculture, 40: 147-161.

Thorpe J.E., 1977: Birnodal distribution of length of juvenile Atlantic salmon (Salmo salar L.) under artificial rearing conditions. - J. Fish. Biol., 11: 175-184.

Tišcenko Ju.F., 1981: Korrelacija morfologičeskich priznakov u nepolozrelych ryb vyrašcennych $v$ sadkach. - Sb. nauč. tr. Gos NIOKCh, 166: 60-68. (in Russian)

Waluga D., 1980: Ocena stanu zdrowotnego młodych stadiów ryb głębielowatych w jeziorowym chowie sadzowym. [Evaluation of health of juvenile coregonids in a lacustrine cage culture]. Raport on Research Project IRS-5 51; manuscript.

Wohlfarth G.W., 1977: Shoot carp. - Badmidgeh, 29,2: 35-40.

Worniałło E., Mamcarz A., 1985: Rearing of coregonid fishes (Coregonidae) in illuminated lake cages. IV. Gonad development in whitefish (Coregonus lavaretus L.) under conditions of cage culture. Aquaculture, 49: 31-40.

Yamagishi H., 1969: Postembryonal growth and its variability of the three marine fishes with special reference to the mechanism of growth variation in fishes. - Res. Popul. Ecol., 11, 1: 14-33.

Translated: Dr. T. Radziejewska

\title{
Andrzej Mamcarz
}

\author{
RÓŻNICOWANIE SIĘ ROZMIARÓW CIAŁA DWU GATUNKÓW \\ RYB GŁABIELOWATYCH (COREGONIDAE) \\ W WARUNKACH DŁUGOTRWAŁEGO CHOWU W SADZACH OŚWIETLONYCH
}

\section{STRESZCZENIE}

U dwóch gatunków Coregonidae (Coregonus lavaretus L. i Coregonus peled Gmelin), przetr zymywanych w sadzach oświetlonych od wylęgu do dojrzałości płciowej, podjęto próbę obserwacji różnicowania się rozmiarów osobników oraz zmian wewnątrz stad w czasie długotrwałego chowu. Zróżnicowanie rozmiarów ryb określano współczynnikiem zmienności (CV), natomiast zmiany w strukturze stad - współczynnikiem skośności rozkładu (SK).

Stwierdzono, że zmiany w charakterze zróżnicowania rozmiarów ryb oraz różnice $w$ charakterze rozkładów długości i masy osobników są przejawem pewnego mechanizmu regulacyjnego w stadach, będącego efektem komıpleksowego oddziaływania szeregu czynników ekologicznych (baza pokarmowa, konkurencja o pokarm, zakwity okrzemek, pasożyty i epizoocje). Czynniki te najsilniej wpływają na charakter stad ryb $\mathrm{w}$ pierwszym $\mathrm{i}$ drugim roku chowu, kształtując poziom śmiertelności Coregonidae w sadzach. U ryb starszych zmiany CV i SK są odbiciem niektórych zjawisk masowych jak długotrwałe epizoocje lub dojrzewanie płciowe poszczególnych osobników.

Author's address:

Received: 1987.01 .09

Dr. Andrzej Mamcarz

Akademia Rolniczo-Techniczna

Katedra Rybactwa

10-957 Olsztyn-Kortowo

Polska (Poland) 